\title{
Katekese Virtual kepada Korban Bencana Alam di Masa Pandemi Menurut Model Berteologi Kosuke Koyama
}

\author{
Antonius Denny Firmanto ${ }^{{ }^{*}}$, Mathias Jebaru Adon ${ }^{2}$ \\ 1 Sekolah Tinggi Filsafat Widya Sasana Malang, Indonesia; rm_deni@yahoo.com \\ 2 Sekolah Tinggi Filsafat Widya Sasana Malang, Indonesia; mathiasjebaruadon@gmail.com \\ * Correspondence: rm_deni@yahoo.com
}

Received: 2021-04-17; Accepted: 2021-07-07; Published: 2021-08-27

\begin{abstract}
Currently, Indonesia is entering difficult phases because the Indonesian nation is not only dealing with the storm of the Covid-19 pandemic but also natural disasters. This disaster brought a traumatic experience for the victims. Healing for victims can indeed be done with a psychological approach, but strengthening faith is no less important. Based on this, the focus of research studies is on the role of religious institutions, particularly the Church, in handling victims of natural disasters. The role of the Church is seen in catechesis. In catechesis, the Church teaches the values of the gospel and confirms the faith of the people that the suffering experienced is not a curse from God. During a pandemic, catechetical work can be done by utilizing virtual spaces such as social media content. Social media is a means of proclaiming the faith that is easily accessible by the people. This kind of catechetical and theological method was initiated by Kosuke Koyama. According to Koyama, the right catechesis model must start from the concrete problems of the people. Based on this, this research study uses the literature study method. Literary sources were researched and analyzed so that a catechetical model was found that was appropriate to the social context of the Indonesian people who were being hit by natural disasters.
\end{abstract}

Keywords: Catechesis; natural disasters; theology of Kosuke Koyama; virtual spaces.

Abstrak: Saat ini Indonesia memasuki fase-fase yang sulit karena Bangsa Indonesia tidak hanya berhadapan dengan badai pandemi Covid-19 tetapi juga bencana alam. Bencana ini membawa pengalaman traumatik bagi para korban. Penyembuhan bagi para korban memang dapat dilakukan dengan pendekatan psikologi tetapi penguatan secara iman tidak kalah penting. Berdasarkan hal itu, fokus studi penelitian pada peran lembaga religius secara khusus Gereja dalam penanganan korban bencana alam. Peran Gereja tampak dalam karya katekese. Dalam katekese, Gereja tidak hanya mengajarkan nilai-nilai injil tetapi meneguhkan iman umat bahwa penderitaan yang dialami bukanlah kutukan dari Allah. Di masa pandemi karya katekese dapat dilakukan dengan memanfaatkan ruang virtual seperti konten-konten media sosial. Media sosial adalah sarana pewartaan iman yang mudah diakses oleh umat. Metode katekese dan teologi semacam ini yang digagas Kosuke Koyama. Menurut Koyama model katekese yang tepat mesti berangkat dari persoalan konkret umat. Berdasarkan hal tersebut studi penelitian ini menggunakan metode studi kepustakaan. Sumber-sumber kepustakaan diteliti dan dianalisis sehingga ditemukan model katekese yang sesuai dengan konteks sosial masyarakat Indonesia yang sedang dilanda bencana alam.

Kata Kunci: Bencana alam; katekese; ruang virtual; Teologi Koyama.

\section{Pendahuluan}

Katekese adalah kegiatan sentral setiap agama misioner. Dalam katekese, isi yang terkandung dalam kitab suci dan materi kabar gembira iman diwartakan. Pewartaan itu dapat dilakukan melalui pengajaran dan katekese seperti pendalaman dan pendidikan iman serta kesaksian hidup sehari-hari sesuai dengan panggilan dan tugas pelayanan masing-masing. Di masa pandemi Covid-19 pewartaan 
Kabar Gembira menjadi mendesak untuk diwujudkan. Pandemi Covid-19 telah membawa dampak yang luar biasa bagi hidup manusia. Badai ini terbukti telah memporakporandakan dunia, tidak hanya sektor perekonomian tetapi nyaris semua sektor (Darmawan, Miharja, Waluyajati, \& Isnaeniah, 2020). Dalam situasi darurat ini, Gereja sebagai persekutuan murid-murid Kristus ditantang untuk mentransformasikan diri secara cepat dan kreatif dalam mewartakan iman (Jubba, 2021). Hal ini berkaitan metode pelaksanaan katekese yang menuntut agar pola pengerjaanya dilakukan dengan memanfaatkan kemajuan teknologi informasi dan komunikasi.

Metode katekese virtual ini dapat dijalankan dengan memanfaatkan konten-konten media dan komunikasi sosial seperti Facebook, Whatssapp, Instgram dan Youtube (Dey \& Daro, 2016). Di samping itu, gagasan teologi pun mesti berangkat dari konteks masyarakat Indonesia yang sedang dilanda pandemi dan bencana alam. Model katekese yang berangkat dari persoalan konkret umat semacam itulah yang digagas oleh Koyama sebagai Teologi Kerbau. Teologi Kerbau adalah model teologi Koyama yang berangkat dari persoalan konkret petani Thailand (Koyama, 1974). Melalui pendekatan Teologi Kerbau ala Koyana gagasan teologis dapat menyentuh dan menjawab persoalan konkret umat. Model berteologi demikian sangat tepat dengan konteks Indonesia karena dapat menyapa dan mengajak umat semakin dekat pada pengenalan akan Kristus (Moe, 2017). Gagasan biblisnya terletak pada inkarnasi Kristus yang masuk dalam kebudayaan Yahudi, "Janganlah kamu menyangka, bahwa Aku datang untuk meniadakan hukum Taurat atau kitab para nabi. Aku datang bukan untuk meniadakannya, melainkan untuk menggenapinya (Mat 5:17).

Berkaitan dengan kondisi Bangsa Indonesia yang saat ini tidak hanya sedang dilanda wabah pandemi Covid-19 tetapi juga bencana alam Gereja dipanggil untuk memberi perhatian, meningkatkan kepedulian dan tindakan partisipatif dalam menjaga, memperbaiki, melindungi dan melestarikan keutuhan ciptaan dari berbagai macam kerusakan (Nota Pastoral KWI, 2013). Disinyalir memasuki awal tahun 2021, terjadi 154 bencana alam di Indonesia (Hastuti, 2021). Menurut keterangan resmi BNPT yang dikutip dari laman Twitter, Sabtu 23 Januari 2021, secara beruntun berbagai peristiwa bencana terjadi, seperti banjir, longsor, gempa bumi dan jatuhnya pesawat Sriwijaya Air SJ-182 (Republika, 2021). Gereja Katholik Indonesia memandang situasi darurat ini sebagai lonceng yang mengingatkan akan pengelolaan lingkungan yang tidak seimbang. Oleh karena itu Gereja menegaskan bahwa ciptaan lain sebagai saudara-saudari yang harus dirawat dan bumi dipandang sebagai rumah bersama yang harus dirawat dan dilestarikan (Fransiskus, 2015). Dengan kata lain bencana alam yang terjadi bukanlah kutukan atau pandemi Covid-19 bukalah kutukan atau penyakit dari Allah tetapi indikasi yang menunjukkan relasi antara manusia dengan alam tidak harmonis.

Berdasarkan hal tersebut penderitaan akibat bencana alam di Indonesia tidak dipandang sebagai sesuatu yang datang dari Allah tetapi realitas yang tidak terlepas dari tindakan manusia yang menjadikan dirinya sebagai pusat ciptaan (Fransiskus, 2019). Oleh sebab itu dalam situasi krisis ini, katekese iman mendapat perhatian utama. Sebab tidak dapat dipungkiri bencana alam tidak hanya mengalami kerugian harta benda, kerusakan lingkungan dan korban jiwa tetapi juga menimbulkan pengalaman traumatik bagi korban yang masih hidup. Kementerian Keuangan mencatat rata-rata kerugian akibat bencana di Indonesia sekitar 22, 85 triliun (Iman Rahman Cahyadi, 2021). Kerugian ini menyebabkan para korban mengalami gangguan psikis mulai dari gangguan ringan seperti perasaan tidak tenang, sangat takut, serta kegelisahan yang tidak berakhir hingga gangguan jiwa (Makahaghi \& Surudani, 2021).

Kondisi trauma biasanya diawali oleh stress yang berkepanjangan yang tidak dapat diatasi sendiri oleh korban. Akibatnya menimbulkan beban psikologis yang berat sehingga menghambat perkembangan emosi dan sosial seperti penyesuaian diri dalam berbagai aspek kehidupan yang tampak dalam sikap dan perilaku seseorang (Khairul Rahmat \& Alawiyah, 2020). Dalam kondisi seperti ini, diperlukan tidak hanya layanan konseling tetapi juga penguatan secara iman. Iman yang mantap akan memudahkan seseorang menerima dengan sukarela peristiwa traumatik yang dialaminya dan bertahan.

Pengalaman traumatik yang berat memang dapat dideteksi dengan pendekatan konseling yang holistik dan berkesinambungan (Khairul Rahmat \& Alawiyah, 2020). Namun penguatan secara iman 
juga tidak kalah penting, karena dengan iman orang dapat melihat penderitaan sebagai ujian bagi iman bahkan sebagai godaan dalam hidup (Siahaya, Siahaya, \& Rinukti, 2020). Dalam teologi kristiani penderitaan yang dialami manusia bukanlah suatu kutukan atau penyakit dari Allah. Penderitaan adalah pengalaman gelap dan getir yang menguji kesetiaan iman seseorang. Sebab setiap orang pasti akan mengalami penderitaan, meskipun dengan tingkat yang berbeda-beda (Rantesalu, 2020). Tetapi penderitaan yang dialami tidak akan melampaui batas kemampuan manusia, semuanya tergantung bagaimana setiap orang menanggapinya. Singkat kata, melalui iman seseorang dapat mengubah penderitaan menjadi anugerah yang menghasilkan buah-buah rohani dengan menyatukannya dalam penderitaan Kristus (Stevanus, 2019). Karena itu, Gereja memandang kesengsaraan atau penderitaan sebagai godaan terbesar dalam hidup orang beriman (KGK 1500).

Karena itu, pewartaan Injil di masa pandemi mesti mengantar umat pada pemahaman bahwa bencana alam yang sedang menimpa beberapa tempat di Indonesia bukanlah kutukan atau hukuman dari Allah. Orang kristiani harus sampai pada kesadaran bahwa Allah tidak merencanakan yang jahat bagi manusia sebab pada hakikatnya Allah adalah kasih. Kasih-Nya yang besar kepada manusia diwujudkan dalam kehadiran-Nya sebagai manusia dalam diri Yesus (Nouwen, Mcneill, \& Morrison, 1987). Berdasarkan hal ini, Kosuke Koyama seorang teolog Asia asal Thailand memperkenalkan cara hidup penyangkalan diri (crucified mind) untuk dapat berteologi dalam konteks Asia, bukan penonjolan diri (crusading mind) sebagaimana model teologi barat. Crucifiend mind adalah suatu pendekatan teologi yang dimulai dengan mendengarkan cerita umat dan belajar dari perjuangan mereka, lalu memberikan cerita kita sebagai pelengkap cerita mereka (Timo, 2017). Metode inilah yang dipakai Paulus ketika mewartakan Injil di Athena (Kis. 17:21).

Di masa isolasi sosial akibat pandemi Covid-19 dimana setiap orang tidak bisa berkontak secara langsung, katekese iman kepada korban bencana alam dapat dilakukan dengan menggunakan teknologi digital. Dari data yang dihimpun oleh lembaga We Are Social, saat ini pengguna aktif internet di seluruh dunia mencapai 3,17 miliar dan setiap tahun mengalami peningkatan hingga 7,6 persen. Sedangkan pengguna media sosial aktif seperti facebook mencapai 2,2 miliar, serta pengguna mobile phone mencapai 3,7 miliar (Dey \& Daro, 2016). Dengan demikian, menggunakan media komunikasi digital untuk mewartakan Injil adalah keharusan bagi Gereja. Sebab melaluinya pewartaan iman semakin hidup, karena media digital memiliki sifat dialogis-resiprokal. Materi yang dibagikan dalam katekese akan mendapat umpan balik (feedback) berupa tanggapan balik seperti like atau balasan berupa komentar. Hal ini menunjukkan dengan sangat benderang bahwa melalui media sosial komunikasi iman menjadi lebih hidup. Pewarta dan penerima warta (followers)terjalin suatu relasi timbal-balik yang egaliter (Dey \& Daro, 2016). Berkaitan dengan itu, Paus Yohanes Paulus II melihat internet sebagai sarana baru bagi pewartaan Injil, karena menyediakan peluang-peluang yang baik bagi karya katekese iman serta mudah diakses umat sesuai dengan situasi dan kebutuhannya.

Fokus studi penelitian ini pertama-tama menguraikan situasi sosial bangsa Indonesia yang sedang mengalami krisis akibat bencana alam yang sedang melanda beberapa tempat di tanah air. Situasi darurat ini, diperparah karena badai pandemi Covid-19 belum menunjukkan tanda-tanda penurunan penyebarannya. Berhadapan dengan kondisi ini, Gereja tidak mempunyai alternatif lain untuk melakukan karya katekese selain memanfaatkan media digital. Kedua, metode berkatekese yang tepat untuk konteks Indonesia adalah suatu katekese yang berangkat dari situasi konkret masyarakat Indonesia yang sedang ditimpa bencana alam dan pandemi. Suatu model berkatekese sebagaimana yang ditawarkan oleh Kosuke Koyama. Ketiga, di tengah situasi pandemi Covid-19 katekese mesti disasar dengan memanfaatkan ruang virtual. Seperti penggunaan dan pemanfaatan konten-konten digital dan media sosial sehingga memudahkan umat dari berbagai lapisan untuk mengaksesnya. Selanjutnya studi penelitian ini memberi sumbangan berharga bagi model katekese yang kontekstual dan berdaya gugah di Indonesia.

Studi penelitian tentang pentingnya katekese virtual telah banyak dijalankan semenjak Gereja memandang media komunikasi digital sebagai sarana dan medan pewartaan iman. Misalnya penelitian yang dilakukan oleh Agustinus Manfred Habur (2018) yang melihat media digital sebagai anugerah Tuhan jika dimanfaatkan secara bijaksana. Karena itu ia melihat media komunikasi digital 
sebagai peluang bagi Gereja untuk melaksanakan katekese keluarga (Habur, 2018). Penegasan yang sama yang diteliti oleh Raharso, A. Tjatur (2019) dalam penelitian tentang reksa pastoral Gereja dalam revolusi 4.0 bahwa, Gereja hendaknya memanfaatkan segala peradaban manusia secara sah dan halal (Raharso, 2019).

Penelitian ini memberi penekanan khusus pada pentingnya pemanfaatan media digital sebagai sarana katekese di masa pandemi. Oleh sebab itu Gereja dituntut untuk segera beradaptasi dengan media digital dengan memanfaatkan konten-konten media sosial. Di sisi lain tugas ini mendesak untuk dikerjakan karena saat ini Indonesia tidak hanya berhadapan dengan pandemi Covid-19 tetapi juga bencana alam. Kehadiran Gereja sebagai institusi religius sangat diharapkan untuk memberikan peneguhan dan penghiburan bagi para korban. Penguatan melalui pemahaman religius diyakini jauh lebih membantu para korban untuk segera keluar dari pengalaman traumatik. Penelitian ini misalnya dilakukan oleh Meidiana Dwidiyanti et al (2018) yang menemukan penguatan secara religius lebih mudah menyembuhkan para korban bencana alam sehingga dapat melihat kehidupan secara bijaksana. Dalam nada yang sama, Johannis Siahaya, Karel Sihaya dan Nunuk Rinukti (2019), meneliti peran penting Gereja sebagai institusi agama yang dipanggil untuk menyembuhkan para korban bencana. Menurutnya, Gereja harus mampu mengantar para korban pada kesadaran bahwa, Allah tidak merencanakan bencana bagi manusia, karena pada hakikatnya Allah adalah kasih.

Hal yang sama juga yang diteliti oleh Hayatul Khairul Rahmat dan Desi Alawiyah (2020) yang mengemukakan penting konseling traumatik kepada korban bencana alam. Namun karena kondisi darurat dan beratnya penderitaan yang dialami para korban maka dibutuhkan suatu rancangan teologi yang menyentuh, meneguhkan dan menghibur umat. Ebenhaizer I. Nuban Timo (2017) memperkenalkan metode berteologi Kosuke Koyama yang menurut penulis sangat cocok untuk berkatekese kepada korban bencana alam. Kosuke Koyama memperkenalkan cara berteologi penyangkalan diri (crucified mind) dan bukan penonjolan diri (crusading mind) sebagaimana model teologi barat. Dengan pendekatan teologi Koyama, para korban akan diteguhkan untuk dengan mudah menerima peristiwa traumatik yang dialaminya. Kekhasan studi penelitian ini terletak dalam metode katekese iman kepada korban bencana alam melalui metode teologi Koyama yang memanfaatkan teknologi digital. Ditengarai pewartaan melalui media digital dapat menjangkau banyak korban dari berbagai tempat di Indonesia. Penelitian yang dilakukan Remigius Missa (2020), menemukan bahwa pewartaan, pengajaran dan perayaan iman yang memanfaatkan media baru seperti radio streaming, perayaan liturgi secara online/live streaming, internet dan facebook, mampu melayani umat dengan baik, karena tidak dibatasi jarak dan tempat, dan diberikan pada waktu yang sesuai dengan kebutuhan umat (Missa, 2020). Dalam penelitian tersebut ditemukan tidak sedikit umat yang terbantu, terberkati dan merasakan kehadiran Allah.

\section{Metode Penelitian}

Penelitian ini menggunakan metode studi kepustakaan dengan mengkaji sumber-sumber yang berkaitan dengan pokok persoalan yang sedang digarap. Sumber data penelitian dibagi menjadi 2 bagian yakni sumber data primer dan sumber data sekunder. Sumber data primer berasal dari dokumen-dokumen Gereja dan ajaran-ajaran Gereja seperti, Dekrit Inter Marifica (1963) yang berisi upaya-upaya Gereja dalam membangun komunikasi-komunikasi sosial. Dalam dokumen pendek ini Gereja berpandangan positif dengan berbagai media komunikasi seperti koran, televisi dan radio (Iswarahadi, 2013). Hal yang sama juga di tekankan oleh Yohanes Paulus II dalam Surat Apostolik 24 Januari 2005 yang melihat internet sebagai sarana dan peluang bagi karya katekese untuk mewartakan Kristus ke seluruh dunia. Namun Gereja juga menekankan pentingnya etika dalam berinternet dan posisi Gereja yang menempatkan perkembangan baru ini untuk melaksanakan perutusan-Nya. Hal ini ditegaskan dalam dokumen Gereja dan Internet; Etika dalam Internet yang dikeluarkan oleh Dewan Kepausan 22 Februari 2002 pada hari komunikasi sosial. Dokumen-dokumen ini dipelajari dan dianalisis secara mendalam sehingga dipahami sikap Gereja terhadap perkembangan media komunikasi dan perutusan Gereja untuk memanfaatkan media komunikasi digital bagi pewartaan 
kabar baik secara khusus bagi pengembangan karya katekese (Dewan Kepausan untuk Komunikasi Sosial, 2019).

Selain itu penelitian ini juga menganalisis tanggapan Gereja Katolik Indonesia terhadap fenomena bencana alam di Indonesia sebagaimana tertuang dalam Nota Pastoral (KWI) tahun 2012 yang berjudul Keterlibatan Gereja Dalam Melestarikan Keutuhan Ciptaan. Dokumen ini dijadikan sumber utama untuk memahami pandangan Gereja secara khusus Gereja Katolik Indonesia dalam menanggapi fenomena bencana alam (Nota Pastoral KWI, 2013). Sumber data sekunder diperoleh dari jurnal ilmiah yang berkaitan dengan katekese virtual, model berteologi ala Kosuke Koyama dan bencana alam. Selain itu, penelitian ini juga memanfaatkan pemberitaan surat kabar online sejak Januari-Februari 2021 untuk meng up to date peristiwa bencana alam di tanah air. Data-data ini dihimpun, dianalisis kemudian dibuatkan sebuah sintesis baru sehingga menjadi landasan dasar penelitian ini. Hasil sintesis ini selanjutnya dikaji ulang untuk menemukan langkah praktis bagi model katekese iman di Indonesia yang saat ini sedang dilanda musibah bencana alam dan wabah pandemi Covid-19. Penelitian ini diharapkan menjadi suatu metodologi baru bagi cara katekese Injil yang kontekstual di Indonesia.

\section{Indonesia Negeri Rawan Bencana Alam}

Indonesia adalah negara yang subur dan kaya akan sumber daya alam. Berlimpah dan beranekaragam satwa dan fauna. Namun, tersimpan ancaman bencana alam yang tinggi. Hal ini disebabkan karena secara geografis Indonesia berada di dalam kawasan Ring of Fire, rentetan gunung berapi yang mengelilingi cekungan Samudra Pasifik. Ancaman itu dapat berupa gunung meletus, gempa bumi, tsunami, tanah longsor, banjir dan lain sebagainya. Data Badan Perserikatan BangsaBangsa untuk Strategi Internasional Pengurangan Risiko Bencana (UN-ISDR) menempatkan Indonesia sebagai salah satu negara yang rawan bencana alam (BBC, 2011). Status ini meningkat pada tahun 2020 yang menempatkan Indonesia sebagai salah satu negara rangking tertinggi rawan bencana. Doni Monardo, Kepala Badan Nasional Penanggulangan Bencana (BNPB) mengungkapkan bahwa, World Bank mendeklarasikan Indonesia dengan tingkat ancaman risiko bencana alam tertinggi di dunia. Posisi ini dihitung dari jumlah korban jiwa bila terjadi bencana alam. Sebanyak 5,4 juta orang akan terpapar apabila terjadi tsunami, dan 11juta orang akan berada dalam resiko gempa bumi, serta sebanyak 1 juta orang yang akan terdampak bila terjadi banjir. Tahun 2020 yang lalu, terjadi 3.253 bencana alam, dan dalam 10 tahun terakhir korban jiwa akibat bencana sekitar 1.183 (Wijiyo, 2021). Besarnya angka data-data ini menunjukkan indikasi lemahnya manajeman bencana alam di Indonesia, baik sebelum bencana, ketika terjadi bencana maupun setelah bencana.

Dengan kata lain bencana sangat dekat dengan masyarakat, bahkan hidup bersama dengan masyarakat Indonesia. Karena itu, Presiden Joko Widodo mengingatkan jajarannya agar tidak hanya sibuk membuat aturan, tetapi yang paling utama bagaimana aturan itu dilaksanakan di lapangan. Pernyataan ini disampaikan oleh Presiden saat membuka Rakornas Penanggulangan Bencana pada 3 Maret 2021 di Istana Negara (Rizky, 2021). Artinya Indonesia perlu belajar manajemen bencana secara tepat. Sebab sebuah keniscayaan mengurangi risiko bencana tanpa manajemen yang baik. Manajemen bencana yang baik dapat dilakukan melalui kegiatan mitigasi bencana sehingga masyarakat dapat mengendalikan bencana dalam keadaan darurat, dan sekaligus masyarakat memiliki kerangka kerja dalam menolong sesama saat keadaan berisiko tinggi. Di sisi lain, sudah saatnya pemerintah menyusun program pembangunan berbasis klimatologis yang merancang kota berbasis iklim. Dimana parameter cuaca dijadikan signifikansi perumusan regulasi. Tujuannya agar saat musim hujan, kota-kota tidak selalu terjadi banjir yang merugikan harta benda, apalagi korban jiwa ('Banjir Kalsel Momen Kritis', 2021). Tugas ini merupakan bentuk tanggungjawab pemerintah atas mandat konstitusional UUD 1945, bahwa Negara dengan segala alat kelengkapannya memiliki tanggung jawab untuk memastikan warganya terhindar dari bencana. Salah satunya melalui pemanfaatan teknologi sistem peringatan dini bencana, serta usaha pemerintah dalam menumbuhkembangkan kesadaran masyarakat tanggap bencana (Wijoyo, 2021).

Namun perlu juga diakui bahwa dari bencana yang terjadi selama beberapa tahun terakhir, pemerintah telah menunjukkan progresivitasnya dari sikap responsif menjadi usaha pengurangan 
risiko yang lebih menekankan pada upaya mitigasi dan pembangunan masyarakat sigap bencana. Keseriusan pemerintah ditandai dengan menerbitkan Rencana Aksi Nasional Pengurangan Risiko Bencana pada Januari 2007 dan Undang-Undang tentang Penanggulangan Bencana No. 24 pada Tahun 2007. Sikap pemerintah ini sesungguhnya dapat membangun ketangguhan dan kesiagaan masyarakat dalam menangani bencana (Djuraidah, 2009). Artinya, tindakan pencegahan, tanggap darurat dan rehabilitasi yang dilakukan pemerintah tersebut dapat membentuk kesadaran masyarakat, bahwa penyebab utama longsor bukanlah air hujan, melainkan buruknya perlakuan masyarakat kepada alam. Banjir besar yang terjadi di Kalimantan Selatan Januari 2021 lalu, menjadi momen kritis bagi semua pihak, baik masyarakat maupun pemerintah untuk lebih memperhatikan daya tahan tanah dan kelestarian lingkungan. Hal ini ditegaskan oleh Muhadjir Effendi Menteri Koordinator Bidang Pembangunan Manusia dan Kebudayaan pada 21 Februari 2021, yang menyatakan bahwa saatnya membuat koreksi radikal terhadap tata lingkungan dan tata tanah sebab bencana disebabkan karena pengolahan tanah yang tidak bijak ('Banjir Kalsel Momen Kritis', 2021). Karena itu, menurutnya bencana yang terjadi menjadi kesempatan bagi masyarakat setempat untuk menakar dan mengetahui kemampuan daya tahan lingkungannya. Sebab jika daya tahan lingkungan baik, meskipun ada musibah tidak akan memakan korban.

Bencana alam yang sering terjadi di Indonesia ditengarai karena eksploitasi alam yang masif yang menyebabkan ruang hijau dalam arti lingkungan fisik menipis untuk menjadi wilayah resapan (Wijiyo, 2021). Selain itu fenomena La Nina yang sedang terjadi membawa dampak pada meningkatnya intensitas curah hujan yang turut memicu terjadinya banjir, longsor, putting beliung dan banjir Bandang di sejumlah daerah di tanah air (Yahya, 2021). Dalam lingkup global Gletser Himalaya mencair, dan menjadi banjir bandang. Demikian halnya Gletser Namda Devi di Himalaya patah. Penelitian yang dilakukan Science Advance 19 Juni 2019, menyatakan gletser yang mencair pada periode 2000-2016 meningkat 2 kali lipat dibandingkan periode 1975-2000 (Sumartiningtyas, 2021). Persoalannya ancaman hidrometerologi ini tidak diimbangi kepastian sejumlah daerah di Indonesia dalam mengantisipasinya. Berdasarkan data Badan Nasional Penanggulangan Bencana (BNPB) sejak januari 2021 setidaknya 321 orang tewas dan 26 orang hilang akibat bencana.

\section{Berteologi Ala Koyama dalam Konteks Bencana Alam di Indonesia}

Berhadapan dengan realitas sosial bangsa Indonesia yang sedang ditimpa bencana, diperlukan model pewartaan iman yang lahir dari pengamatan mendalam akan kebenaran yang terkandung dalam peristiwa bencana yang terjadi. Kosuke Koyama seorang Teolog Asia yang lahir di Tokyo pada tahun 1929, memperkenalkan Allah dalam situasi nyata kebutuhan para petani di Thailand (Irvin \& Akinade, 2009). Ia menempatkan kebutuhan konkret para petani di atas beberapa pemikiran teologi agung seperti dari Thomas Aquino dan Barth (Ariyanto, 2011). Pemikiran teologisnya dikenal dengan teologi kerbau. Melalui pemikiran teologinya ini, Koyama menunjukkan metode yang dipakai dalam berteologi tidak ditentukan terutama oleh apa yang pernah dikatakan teolog-teolog besar tetapi juga oleh kenyataan sehari-hari yang dialami oleh masyarakat setempat: seperti: kerbau, marica, nanas, ayam, atau nasi pulut (Koyama, 1974). Di sini, Koyama tidak bermaksud mengabaikan atau menganggap sepi teologi- teologi sistematik sebagaimana yang digagas Aquinas, Barth, dan yang lainnya. Tetapi Koyama hendak membangun basis teologi yang tepat sasar untuk Asia dengan membangun suatu teologi dari bawah, yang berangkat dari pergulatan konkret masyarakat setempat (Koyama, 1984). Menurut Koyama, teologi yang sesuai dengan citra Asia adalah teologi penyangkalan diri, bukan penonjolan diri (Timo, 2017). Dengan cara ini Koyama hendak menegaskan bahwa Allah itu dekat dan hadir dalam setiap peristiwa hidup manusia.

Berkaitan dengan situasi bencana alam yang tengah dihadapi bangsa Indonesia diperlukan suatu jawaban teologis atas persoalan bencana alam dalam terang kasih Tuhan. Masyarakat tidak boleh memperoleh jawaban yang berbeda, bahkan menantang pemahaman manusiawi dan ilmu pengetahuan (Budianto, 2018). Musibah yang terjadi bukan rancangan dari Allah, sebagai suatu kutukan atau hukuman atas dosa yang dilakukan manusia. Bencana yang terjadi karena tidak ada komunikasi yang harmonis antara manusia dengan alam semesta (Fransiskus, 2015). Karena itu, 
masyarakat mesti diajari bagaimana berkomunikasi dengan alam. Manusia mempunyai tanggungjawab memberikan kontribusi dalam menjaga keseimbangan hubungan antara manusia, alam, dan Tuhan. Sebagai makhluk yang dikaruniai akal dan nurani, manusia mempunyai kewajiban memastikan semua makhluk dapat berkembang biak (Sunanto, 2014). Hal senada dikatakan oleh Paus Fransiskus bahwa, alam adalah rumah kita bersama. Gambaran rumah ini mengingatkan manusia akan panggilannya untuk menjaga keindahan, kebaikan dan damai bagi semua makhluk dan segenap ciptaan yang ada di seluruh alam raya ini (Henakyn, 2016). Bencana alam yang terjadi karenanya adalah alarm yang mengingatkan manusia akan kewajibannya melestarikan alam. Model berkatekese semacam inilah yang digagas oleh Koyama agar Allah sungguh dikenal oleh umat. Menurut Koyama, khotbah atau katekese iman harus dimulai dari jemaat, dari percakapan tentang situasi, keprihatinan dan pergulatan umat manusia sehari-hari lalu memperkenalkan Allah dalam situasi manusia yang konkret ini (Ariyanto, 2011).

Dalam peristiwa bencana alam, karena dampak buruk yang ditimbulkannya, para korban membutuhkan pegangan iman yang mantap dalam memandang realitas yang terjadi. Bencana alam yang terjadi di Yogyakarta tahun 2006 misalnya dapat menjadi contoh bagaimana pewartaan iman sangat dibutuhkan. Pada waktu itu banyak masyarakat Yogya melihat bencana dalam perspektif mistis karena berat dan sulit realitas bencana dipahami. Akibatnya, terjadi mitologisasi dalam masyarakat. Warga menaruh bambu kuning, janur di atas pintu depan rumah sebagai bentuk tolak bala atas bencana yang terjadi (Sabir \& Phil, 2016). Padahal secara geografis, Gunung Merapi di Yogyakarta adalah gunung api yang paling aktif di antara 130 gunung berapi aktif yang tersebar di berbagai pulau di Indonesia dan bagian selatan Yogyakarta yang didominasi oleh pesisir pantai (Utomo \& Minza, 2018).

Berdasarkan hal tersebut masyarakat harus diberi ilmu yang cukup tentang penyebab dan akibat bencana, karena sebagian besar wilayah di Indonesia merupakan daerah rawan bencana. Perspektif teologis dihadirkan agar manusia menyimak pesan Tuhan lebih jernih. Bencana tidak direncanakan Allah tetapi menjadi lonceng yang mengingatkan keangkuhan manusia. Manusia hanyalah salah satu bagian dari alam semesta yang maha besar. Perusakan masif yang dilakukan manusia membuat gunung, bumi, dan laut geram (Sunanto, 2014). Bencana alam mengingatkan manusia bahwa relasinya tidak hanya sebatas antara sesama manusia, tetapi juga dalam kesatuan dengan alam semesta. Sikap penghargaan kepada alam merupakan pertanggungjawaban manusia sebagai makhluk yang berakhlak mulia. Dalam menjalankan tugasnya itu manusia menjadikan alam bernilai dalam dirinya dengan memperjuangkan kesejahteraan alam dan ciptaan Tuhan yang lain.

Di sisi lain banjir, dan bencana alam yang lain terjadi merupakan peringatan rendahnya mutu pengelolaan lingkungan. Maka, masyarakat perlu mengkritisi sebab dan akibat bencana. Seperti kesadaran bahwa banyaknya korban jiwa yang meninggal dalam musibah gempa sesungguhnya bukan disebabkan oleh gempa buminya. Melainkan juga karena tidak kukuhnya struktur bangunan dalam menahan gempa sehingga banyak bangunan yang roboh menimpa manusia. Selain itu ketidaktahuan tentang apa yang harus dilakukan masyarakat bila terjadi gempa. Demikian halnya yang terjadi dengan musibah banjir dan longsor tidak semata-mata karena faktor alam seperti perubahan musim dan curah hujan yang tinggi. Tetapi juga disebabkan tata ruang yang sembarangan, urbanisasi yang tidak terkendali, lahan permukiman yang merambah tanah resapan, hingga perilaku membuang sampah sembarangan (Asmara, 2021). Dan yang paling berbahaya adalah alih fungsi lahan menjadi lahan industri.

Realitas sosial dan peristiwa-peristiwa semacam inilah yang menjadi inti pokok-pokok tema karya katekese Koyama. Hal ini tampak jelas dalam beberapa sub-judul buku Waterbuffalo Theology, yang menggambarkan suatu rumusan teologi yang berakar dari realitas dan peristiwa setempat seperti, 'Apakah Musim Hujan Membuat Allah Basah', 'Senapan dan Balsem', 'Lada Aristoteles dan Garam Buddhis', dan 'Arahant yang Dingin dan Allah yang Hangat'. Melalui tema-tema seperti ini pesan Kristus dikenali dan dimengerti oleh para pendengar karena menggunakan medium yang dekat dengan dunia masyarakat (Moe, 2017). Metode katekese seperti ini membuat pewartaannya menjadi lebih hidup karena menggunakan gambaran-gambaran yang berangkat dari persoalan dan peristiwa 
yang sedang terjadi di tengah umat, daripada ide-ide abstrak (Dewan Kepausan untuk Komunikasi Sosial, 2019). Dalam konteks Indonesia masa kini disinyalir bahwa bahasa pewartaan iman terkadang sulit dipahami terutama bagi generasi milenial, karena kerapkali merupakan hasil olahan kebudayaan Barat, khususnya zaman abad pertengahan, dengan latar belakang budaya Yunani-Romawi (Pandor, 2018). Karena itu Kosuke Koyama merekomendasikan cara berkatekse tentang Kristus untuk konteks Asia yang dapat didekati dalam dua cara yakni, cara meludahi orang lain dan cara diludahi orang (Koyama, 1974).

Cara pertama menurutnya menunjukkan kedangkalan pemahaman tentang Kristus. Sedangkan cara kedua memperlihatkan kedalaman penghayatan misi, eklesiologi dan teologi. Cara ini tidak segera memvonis sesamanya, tetapi dengan mulai mendengar dan mengenal mereka. Berdasarkan pendengaran itu, Injil diceritakan dalam bahasa yang dipahami sambil menunjukkan bahwa apa yang ada dalam Injil adalah fondasi dan sekaligus pemenuhan dari apa yang mereka pahami (Timo, 2017). Dengan katekese seperti ini mereka mengimani Allah sebagai pribadi yang penuh kasih, komunikatif dan bersahabat dengan manusia (Bala, 2020). Karena itu, dengan berkatekese melalui metode teologi Kosuke Koyama, umat beriman dapat mempelajari ajaran Katolik dengan lebih lengkap dan dapat mempraktekkanya dengan lebih tepat, alias menjadikan iman itu "operatif, aktif, dan produktif" khususnya di tengah beratnya pengalaman bencana alam yang terjadi (Koyama, 1999).

\section{Katekese Iman Kepada Korban Bencana Alam}

Metode berteologi Koyama yang menekankan finalitas Yesus yang didengar dan dilihat dalam tindakan konkret bukan dalam debat filosofis dan diskusi akademis, dapat menjadi metode berkatekese di masa bencana. Bencana alam yang memakan korban jiwa dan kerugian harta benda maupun moril menyebabkan gangguan psikis dan degradasi mental para korban. Sebuah studi yang dilakukan WHO tahun 2013 menunjukkan, setelah peristiwa bencana terjadi terdapat 3-4\% korban akan mengalami gangguan psikis berat seperti psikosis, depresi berat dan kecemasan yang tinggi, sekitar $15-20 \%$ akan mengalami gangguan mental ringan yang merujuk pada kondisi PTSD, sedangkan sebagian besar korban tetap memiliki reaksi psikologis yang normal (Dwidiyanti, Hadi, Wiguna, \& Ningsih, 2018). Berdasarkan hal tersebut penanganan korban bencana membutuhkan bantuan dan penanganan yang serius dari berbagai pihak, secara khusus bagi korban yang mengalami gangguan psikis yang berat. Dampak itu mencakup aspek emosi dan kognitif. Aspek emosi meliputi gejala-gejala seperti cemas, rasa takut, sedih, rasa tidak berdaya, kehilangan emosi positif seperti perasaan cinta, keintiman dan kegembiraan. Sedangkan aspek kognitif seperti pikiran kacau, menurunnya kemampuan untuk mengambil keputusan, daya konsentrasi dan daya ingat berkurang, dan menyalahkan dirinya sendiri (Khairul Rahmat \& Alawiyah, 2020). Peristiwa erupsi gunung Merapi pada bulan Oktober 2010 di Yogyakarta dapat dijadikan bahan perbandingan. Sekitar 5\% atau sebanyak 11.792 dari 235.858 pengungsi mengalami gangguan jiwa pada saat kejadian, terdapat 756 orang mengalami gangguan jiwa pasca peristiwa erupsi, dan 52 di antaranya mengalami gangguan jiwa berat sehingga harus dirawat di rumah sakit jiwa (Siahaya et al., 2020).

Berhadapan dengan kondisi seperti ini diperlukan pelayanan serius, tidak hanya layanan konseling tetapi juga perspektif fikih lingkungan hidup, agar para korban sampai kepada kesadaran bahwa musibah terjadi bukan semata-mata karena cuaca yang ekstrim tetapi juga karena pengelolaan sumber daya alam yang tidak memperhatikan fikih lingkungan hidup. Melalui metode trauma healing yang demikian para korban lebih mudah menerima musibah yang terjadi dengan ikhlas, serta memiliki kesadaran akan pentingnya komunikasi yang harmoni dengan semua alam. Harus diakui bahwa, ketika musibah datang baik yang percaya kepada Tuhan atau tidak akan muncul pertanyaan tentang 'teodisea'; jika ada Tuhan, mengapa ada bencana atau penderitaan (Siahaya et al., 2020). Kehadiran lembaga religius dalam situasi ini sangat diharapkan untuk menguatkan dan memberi pengharapan, karena dengan mendekatkan diri kepada Tuhan akan lebih mudah membantu para korban pulih dari trauma bencana lebih cepat. Sebab kepercayaan dan sikap pasrah kepada Tuhan adalah langkah awal menerima dengan ikhlas musibah yang terjadi. 
Penelitian yang dilakukan Dwidiyanti et al., (2018) menemukan bahwa penguatan secara spiritual mampu menurunkan masalah psikologis yang berat seperti; stress, kecemasan dan depresi, serta dapat mengontrol marah dan menenangkan hati klien, dan mampu meningkatkan kemandirian pasien dalam menjalankan fungsi kehidupannya. Maka dalam penanganan korban bencana alam diperlukan tidak hanya pelayanan psikologis tetapi juga bagaimana membangkitkan kesadaran spiritual-kerohanian para korban. Penguatan secara spiritual ini dapat dilakukan melalui katekese iman. Gereja sebagai salah satu lembaga spiritual-kerohanian dipanggil untuk ikut terlibat dalam menangani persoalan korban bencana.

Panggilan ini merupakan tugas dasariah Gereja sebagai pelaksanaan mandat agung Kristus, "Pergilah dan beritakanlah Kerajaan Surga, sembuhkanlah orang sakit, bangkitkanlah orang mati, tahirkanlah orang kusta dan usirlah setan-setan (Mat. 10:7-8) (Paus Yohanes Paulus II, 1965). Pelaksanaan amanat agung ini dilakukan dalam setiap situasi, di mana saja Gereja berada, dalam komunitas hidup sehari-hari maupun dalam keterlibatan dengan proyek misi, entah sebagai misionaris atau sebagai pengutus (Nainggolan, 2014). Keterlibatan Gereja dengan realitas konkret semacam inilah yang digagas oleh Koyama untuk dapat mewartakan dalam pluralitas persoalan Asia. Dalam keterlibatan ini, Gereja melatih diri untuk hidup dalam citra crucified mind, bukan crusading mind (Timo, 2017). Penekanan pada crucified mind yang dimaksud Koyama tidak berarti teologi meninggalkan crusade for Christ. Tetapi crusade for Christ (kampanye bagi Kristus) tetaplah perlu, tetapi bukan lagi berbicara tentang Kristus sebagai yang final atau unggul melainkan Kristus yang terlibat dengan penderitaan masyarakat setempat (Koyama, 1999).

Para korban bencana alam adalah orang-orang yang sangat membutuhkan bantuan, baik material maupun berbagai bentuk pendampingan dan penguatan secara spiritual. Kehadiran Gereja sebagai lembaga religius diharapkan untuk menjelaskan bahwa penderitaan dan bencana merupakan bagian dari kehidupan yang bisa menimpa siapa saja (Paus Yohanes Paulus II, 1965). Sebab secara eksistensial penderitaan tidak akan pernah absen dari realitas hidup manusia. Penderitaan dan bencana menjadi problem iman di setiap zaman. Penderitaan selalu menyentuh kodrat eksistensial manusia. Ia melekat pada kodrat manusia dan perlahan-lahan menggerogoti berbagai dimensi eksistensi manusia baik fisik, psikologis, moral maupun spiritual. Meski demikian penderitaan tidak akan merampas martabat manusia, suatu martabat yang erat kaitannya dengan kesadaran akan makna kehidupan (Pandor, 2014).

Ada orang dengan mudah menerima penderitaan yang dialaminya dan mengubahnya menjadi buah-buah rohani sehingga semakin beriman saat diuji dalam penderitaan, sementara tidak sedikit juga orang beriman tidak dapat menerima beratnya penderitaan dan kehilangan iman (Stevanus, 2019). Kenyataan ini menjadi penggerak bagi Gereja untuk melakukan karya katekese guna membangkitkan iman dalam menghadapi kenyataan konkrit penderitaan hidup sehari-hari. Karena itu melalui karya katekese mereka yang menderita karena bencana semakin diteguhkan atau dikuatkan imannya akan Yesus Kristus.

Penelitian yang dilakukan oleh Ijaz et al. (2017), sebagaimana yang dikutip oleh Dwidiyanti et al. (2018), menemukan bahwa para korban yang beribadah secara rutin dengan mindfulness atau penuh kesadaran memiliki kesehatan mental yang jauh lebih baik dibandingkan dengan individu yang tidak melakukan ibadah secara rutin. Dengan mindfulness spiritual para korban lebih fokus pada persoalan yang sedang dihadapi, lebih tenang, ikhlas dan tetap mensyukuri apa yang terjadi. Dan selanjutnya mereka dapat membuat rencana tindak lanjut sebagai target sehat mandiri sehingga dapat menjalani aktivitas sehari-hari dengan perasaan lebih tenang dan bahagia. Sebab pada dasarnya sejak awal mula, Allah merancangkan hal yang baik bagi manusia dan ciptaan yang lain dan menciptakan segala sesuatu baik adanya (Kej.1-2). Kebaikan Allah mencapai puncaknya dengan rela merendahkan diri-Nya untuk demi keselamatan manusia (Fil.2:6-11). Dalam cara pandang seperti ini dapat dilihat bahwa Allah pada hakikatnya baik, dan menciptakan segala yang baik (Rantesalu, 2020).

Bagi Gereja tugas berkatekese bukan sebuah pilihan melainkan suatu kewajiban yang dimotivasi oleh upaya penyelamatan manusia. Maka kegiatan katekese menjadi fondasi utama dalam pelayanan Gereja (Manurung, 2020). Sebab pada prinsipnya katekese mengarah pada instruksi atau pengajaran 
mengenai religiusitas atau agama, sehingga melalui karya katekese Gereja akan mengalami pertumbuhan (Tinambunan, 2018). Dengan demikian kisah dan pengajaran iman melalui katekese dengan metode berteologi Koyama dapat mengajak korban bencana alam untuk melihat kembali jawaban atas problem musibah bencana dalam terang kasih Tuhan (Budianto, 2018).

\section{Katekese Virtual Kepada Korban Bencana Alam}

Di hadapan jutaan orang yang mati karena bencana alam, pandemi Covid-19, intoleransi agama dan ekstremisme, Gereja tidak bisa tinggal diam. Gereja dituntut untuk bersaksi lebih intens sebagai perwujudan kehadiran Allah yang memelihara, menguatkan, menyembuhkan dan menyelamatkan. Inilah kesempatan bagi Gereja untuk bersaksi bahwa di tengah penderitaan dunia Gereja tidak lumpuh, Ia hadir sebagai tanda yang selalu membawa harapan (Yohanes Paulus II, 2011). Kehadiran dan keterlibatan Gereja dalam situasi ini menegaskan keyakinan mendasar bahwa Allah senantiasa hadir dalam situasi krisis hidup manusia.

Di tengah badai pandemi Covid-19, kehadiran Gereja yang menyelamatkan disesuaikan dengan kebiasaan-kebiasaan normal baru seperti; bekerja, belajar dan dari beribadah dari rumah. Demikian halnya dengan tugas pengajaran Gereja yang sebelumnya dilaksanakan dengan penyampaian langsung sekarang ditransformasikan dengan memanfaatkan kemajuan teknologi informasi dan komunikasi. Situasi ini menjadi kesempatan bagi Gereja untuk lebih mudah berdialog dan bersaksi dengan orang miskin, antaragama dan antar budaya (Putranto, 2002). Sebab pewartaan iman yang dilakukan dengan memanfaatkan media digital dapat menjangkau semua umat lebih luas dan cepat bahkan menjangkau wilayah yang tak terjangkau dan dengan jumlah umat yang tak terbatas (Dey \& Daro, 2016). Karena itu dalam menjalankan tugas perutusannya mewartakan Kerajaan Allah, Gereja tidak memiliki pilihan lain selain beradaptasi dan membudayakan kehidupan normal baru. Suatu kehidupan baru yang memanfaatkan teknologi sebagai sarana pewartaan, perayaan dan pengajaran iman.

Hal ini sudah disadari Paus Yohanes Paulus II yang menyatakan bahwa Gereja merasa bersalah di hadapan Allah jika tidak menggunakan media digital sebagai sarana mewartakan kabar gembira (Komisi Kateketik KWI, 2015). Gereja menerima dengan gembira dan memandang budaya digital sebagai anugerah Allah dan mengajak umat beriman untuk memanfaatkan sarana-sarana digital bagi pewartaan kabar gembira. Bahkan Paus Yohanes Paulus II lebih jauh menegaskan Gereja tidak hanya memanfaatkan sarana digital sebagai pewartaan Kabar Gembira tetapi juga perlu ada integrasi antara warta kabar gembira dengan budaya baru yang tercipta melalui komunikasi modern (Yohanes Paulus II, 2011). Maka katekese sebagai sarana komunikasi iman yang mengandung unsur baik pengetahuan maupun pengalaman iman dan yang berfungsi meneguhkan, menghayati dan mengembangkan iman dalam pelaksanaannya mesti diintegrasikan dengan budaya digital serta menjadikan wahana virtual sebagai sarananya. Dewan Kepausan untuk Komunikasi Sosial, “Gereja Dan Internet, Etika Dalam Internet, Perkembangan Cepat."

Masa pandemi Covid-19 memaksa Gereja untuk secara maksimal menggunakan media ini bagi pewartaan Injil. Gagasan teologisnya pada peristiwa inkarnasi Allah. Pada hakikatnya Allah senantiasa mengkomunikasikan diri-Nya dan menyapa manusia sepanjang masa. Komunikasi ini mencapai puncaknya dalam diri Yesus. Peristiwa inkarnasi merupakan peristiwa Allah menjumpai manusia di tempat dan konteks budaya tertentu. Meskipun inkarnasi hanya sekali terjadi dalam diri Yesus dari Nazareth, namun Allah tetap menyapa dan menjumpai manusia sampai sekarang sesuai dengan bahasa, cara dan budaya manusia saat ini (Iswarahadi, 2013). Di momen krisis akibat bencana alam yang menelan korban jiwa dan harta benda, Gereja sebagai sarana kehadiran Allah menyapa dan menjumpai para korban melalui budaya digital. Perayaan-perayaan iman dilaksanakan secara online dan pesan-pesan iman yang meneguhkan dibagikan melalui teknologi komunikasi secara khusus media sosial yang mudah dijangkau dan diakses oleh para korban.

Penelitian yang dilakukan Remigius Missa (2020), menyimpulkan bahwa pewartaan, pengajaran dan perayaan iman dengan memanfaatkan media baru seperti radio streaming, perayaan liturgi secara online/live streaming, internet dan facebook, mampu melayani umat dengan baik dan tidak terbatas 
jarak dan waktu. Dalam penelitian itu ditemukan tidak sedikit umat yang terbantu, terberkati dan merasakan kehadiran Allah (Missa, 2020). Dalam ruang virtual ini waktu dan ruang menjadi lebih cair. Pewartaan iman dapat diikuti dari ruang apa saja, tidak diperlukan ruang yang khusus dan waktunya pun menjadi lebih fleksibel (Embu, 2020). Dengan kata lain, karya keselamatan Allah di tengah pandemi Covid-19 tetap dirasakan oleh umat. Kehadiran komunikasi digital karenanya menjadi peluang emas untuk memikirkan terobosan baru dalam pola pengajaran di masa pandemi khususnya bagi korban bencana alam (Iswarahadi, 2013). Dengan demikian katekese konvensional mendapat sentuhan baru karena memanfaatkan kecanggihan komunikasi digital khususnya media sosial yang bisa menjangkau semua umat secara lebih luas dan cepat secara khusus umat yang sedang menderita akibat badai Pandemi dan bencana alam.

Singkat kata, era digital telah merobohkan distansi ruang dan waktu konvensional sehingga menuntut Gereja untuk memanfaatkannya untuk semakin mewartakan dan menjangkau semakin luas umat dengan konten yang baik dan menarik sehingga dapat menumbuhkan dan mengembangkan iman umat. Hal ini menjawab penelitian yang dilakukan Ken Bedell yang mengemukakan bahwa hampir $80 \%$ responden mengatakan bahwa media memainkan peranan dalam kehidupan spiritual mereka. Dalam penelitian itu ditemukan bahwa sebagian besar mereka melihat dan mencari kontenkonten spiritual hingga sampai tiga kali seminggu (Komisi Kateketik KWI, 2015). Berhadapan dengan realitas ini, Gereja tidak bisa lagi mengelak dari media komunikasi digital tetapi memanfaatkannya secara optimal agar umat semakin diantar masuk dalam perjumpaan dengan Allah yang menyelamatkan.

Gereja dapat belajar dari Paulus yang memanfaatkan berbagai media dalam pewartaan Injil. Paulus membiarkan dirinya masuk dalam euforia budaya helenis untuk mewartakan Kristus. Pewartaanya tidak hanya pada pusat-pusat kota tetapi juga Gereja-Gereja rumah, dan meluas tidak hanya dalam lingkungan Yahudi tetapi juga orang-orang Yunani. Karena itu, media komunikasi digital mesti dilihat sebagai Aeropagus baru dalam pewartaan iman. Pewartaan dan katekese iman dengan komunikasi digital menjadi mendesak untuk dilaksanakan saat ini karena beratnya penderitaan umat yang saat ini sedang dilanda bencana alam dan badai Pandemi Covid-19 yang belum menunjukkan penurunannya. Hal ini telah ditegaskan oleh Yohanes Paulus II dalam Pesan untuk Hari Komunikasi Sosial sedunia yang mengundang seluruh Gereja untuk dengan berani melintasi ambang pintu yang baru ini dan mengayuh ke kedalaman jaringan internet sehingga sekarang sebagaimana dulu interaksi antara Injil dan budaya dapat memperlihatkan kepada dunia 'kemuliaan Allah dalam wajah Kristus' (2 Kor 4:6) (Purwatma, 2016).

\section{Katekese Virtual Kepada Korban Bencana Alam Menurut Teologi Kosuke Koyama}

Di masa isolasi sosial akibat pandemi covid-19 dan bencana alam, realitas penderitaan menjadi semakin besar yang ditandai rasa putus asa dan frustrasi. Hasil survei yang dilakukan Perhimpunan Dokter Spesialis Kedokteran Jiwa Indonesia (PDSKJI) melalui swaperiksa yang dilakukan secara daring menemukan sebanyak 63 persen responden mengalami cemas dan 66 persen responden mengalami depresi akibat pandemi Covid-19 (Ridlo, 2020). Perasaan yang timbul ditandai rasa khawatir akan sesuatu yang buruk, mudah marah, dan sulit rileks. Dalam konteks global krisis ini didominasi oleh perasaan ketidakpastian, kekecewaan, kecemasan akan masa depan dan pengendalian kepentingan ekonomi yang sempit. Karena itu dibutuhkan komunitas yang dapat mendukung dan membantu manusia untuk dapat membantu satu sama lain agar tetap menjaga pandangan ke depan. Gereja sebagai salah satu komunitas kasih diharapkan dapat menyalakan kembali daya rohani yang suram akibat beratnya realitas penderitaan. Gereja memulai kesaksiannya dengan terbuka untuk menyatakan harapan dan kasih Allah kepada dunia, secara khusus bagi mereka yang menderita akibat wabah pandemi dan bencana alam (Paus Yohanes Paulus II, 1965). Penguatan ini dilakukan dengan pengajaran yang meneguhkan dan menguatkan iman. Caranya dengan menggunakan media komunikasi digital secara khusus media sosial. Media sosial disinyalir mudah diakses dan dijangkau oleh umat dimana dan kapan pun. Pengajaran atau katekese iman yang berangkat dari realitas konkret pergulatan umat adalah suatu karya katekese yang ditawarkan dalam Koyama (Mathiesen, 1998). 
Perjumpaan dengan Allah yang hidup menurut Koyama ditemukan dalam realitas konkret hidup manusia sehari-hari (Koyama, 1997).

Di tengah krisis akibat bencana alam dan isolasi sosial akibat pandemi, materi pengajaran iman mestinya berangkat dari kesadaran dan refleksi bahwa Allah hadir dan terlibat dalam kecemasan dan ketakutan manusia. Allah bukanlah Allah yang jauh, yang harus ditakuti dan dihindari, atau Allah pemalas tetapi Allah yang tergerak oleh penderitaan manusia. Dia terlibat dengan penderitaan manusia; menangis dengan mereka yang mencucurkan air mata, ringkih bersama yang ringkih dan berkorban bersama para relawan. Maka pewartaan akan Allah yang menderita yang tidak jauh dari penderitaan manusia inilah yang memungkinkan pengajaran dan karya katekese Gereja memiliki daya di masa pandemi.

Pewartaan tentang Allah yang terlibat dalam sejarah hidup manusia yang konkret sebagaimana yang tampak dalam teologi Koyama menjadi metodologi bagi Gereja untuk memberikan peneguhan agar umat sampai kesadaran bahwa Allah tidak merencanakan yang jahat dalam hidup manusia. Pandemi Covid-19, bencana alam bukanlah suatu kutukan atau penyakit dari Allah tetapi realitas yang harus diterima manusia, dan bahwa semua bentuk penderitaan yang terjadi semata-mata tidak terlepas juga dari pengelolaan alam dan lingkungan yang tidak memperhatikan keseimbangan ekosistem serta pemanfaatan teknologi yang berlebihan (Nota Pastoral KWI, 2013).

Katekese Kosuke Koyama tentang keterlibatan Allah dalam pengalaman pergulatan manusia dan pengajaran fikih tentang lingkungan hidup dapat dilakukan Gereja dengan memanfaatkan kontenkonten media sosial; facebook, Instagram, youtube dan whatsapp. Penggunaan media-media ini sangat marak terjadi di masa pandemi seperti fenomena misa online yang menggunakan platform media sosial facebook yang memungkinkan banyak orang dari berbagai tempat dan mengikuti perayaan tersebut (Embu, 2020). Misa online tentunya memberikan sebuah pengalaman religius baru, menarik dan unik karena ritual yang sebelumnya dilakukan secara offline kini termediasi oleh sarana virtual yang bisa diikuti dimana saja dan praktis. Hal yang sama yang terjadi dari hasil penelitian Andreas Aji Brata (2019) yang menemukan manfaat penggunaan media sosial Whatsapp dalam pewartaan iman bagi umat di Lingkungan Santo Tarsius Sidomulyo Paroki Santo Yosep Mendari Yogyakarta yang menggunakan media sosial ini sebagai media membagikan renungan dan bacaan harian (Brata, 2019). Dengan cara ini umat pun dapat saling meneguhkan satu sama lain.

Dengan demikian karya katekese di masa pandemi covid-19 secara khusus bagi korban bencana alam tetap terlaksana karena memanfaatkan komunikasi digital melalui konten-konten yang terdapat dalam media sosial. Dengan bantuan media ini karya katekese menjadi menarik karena pengajaran iman dibantu alat peraga seperti; gambar, video, warna, dan grafis sehingga pengajaran menjadi lebih dinamis dan hidup. Di sisi lain selain penggunanya yang praktis dan murah, media digital dapat meneguhkan iman umat yang menderita, juga pada saat yang sama menghibur umat karena kekayaan kreativitas yang ditampilkan. Hal ini misalnya yang terjadi dengan karya katekese yang digunakan dalam penggunaan website katolisitas yang menawarkan kemudahan untuk mengakses ajaran iman Katolik yang lengkap dan benar tanpa dibatasi oleh ruang dan waktu (Kristianto, 2016). Pewartaan iman yang menjawab persoalan konkret hidup harian seperti ini yang diharapkan oleh Koyama agar Allah semakin dikenal dan iman umat semakin berdaya ubah bagi Gereja lokal setempat.

\section{Kesimpulan}

Pelaksanaan pengajaran iman atau karya katekese sebagai salah satu panca tugas Gereja di masa pandemi mendesak untuk dikerjakan. Pada masa sulit ini bangsa Indonesia tidak hanya menghadapi darurat kesehatan karena pandemi Covid-19 yang menghantam semua sistem dan menelan korban jiwa tetapi juga rakyat Indonesia berada dalam darurat bencana alam. Di awal tahun 2021, terjadi rentetan bencana alam hampir di seluruh bagian di Indonesia. Bencana tersebut membawa luka yang mendalam dan pengalaman traumatik karena tidak sedikit nyawa yang melayang. Gereja sebagai salah satu lembaga religius tidak dapat tinggal diam melihat penderitaan umat. Gereja dipanggil untuk membawa harapan melalui perbuatan kasih. Gereja mewujudkan panggilan dasariah ini melalui penguatan dan katekese iman. Di masa sulit ini karena pandemi, Gereja tidak dapat melaksanakan 
karya katekese secara maksimal seperti sebelum pandemi. Dalam situasi ini, Gereja dituntut untuk beradaptasi dengan mematuhi protokol kesehatan normal baru. Karya katekese semacam inilah yang digagas oleh Kosuke Koyama agar iman sungguh menyentuh persoalan konkret umat. Berkaitan dengan hal ini Koyama memperkenalkan Teologi Kerbau. Teologi Kerbau ala Koyama sangat tepat untuk mewartakan iman di tengah situasi Bangsa Indonesia yang sedang dalam darurat bencana alam dan pandemi Covid-19. Sebab bencana alam dan pandemi tidak hanya membawa luka yang mendalam tetapi juga pengalaman traumatik sehingga menimbulkan stress dan frustrasi yang panjang.

Pengalaman traumatik memang dapat disembuhkan dengan psikologi yang holistik tetapi penguatan dengan iman jauh lebih berdaya ubah bagi para korban. Hasil penelitian yang dilakukan Dwidiyanti et al., (2018) terhadap korban bencana gempa di Lombok NTB menunjukkan bahwa, penguatan secara spiritual mampu menurunkan masalah psikologis yang berat seperti; stress, kecemasan dan depresi (Dwidiyanti et al., 2018). Dalam iman, para korban dapat melihat bahwa bencana alam yang terjadi semata-mata bukan karena kutukan atau penyakit dari Allah tetapi juga karena pengelolaan lingkungan hidup yang tidak seimbang. Melalui pendekatan religius para korban disadarkan akan panggilan dasarnya untuk mengolah alam secara bijaksana. Bencana yang terjadi adalah lonceng yang mengingatkan tugas dan kewajiban tersebut. Dalam perspektif ini para korban lebih mudah menerima pengalaman bencana dan dapat melanjutkan hidupnya dengan lebih bijaksana. Sebab penderitaan pada dasarnya tidak hanya menorehkan pengalaman luka tetapi juga mengandung nilai pedagogis.

Gereja melihat hal ini sebagai peluang untuk semakin memperkenalkan Allah sebagai Dia yang turut menderita bersama manusia. Sebab pewartaan iman di masa sulit akan jauh memberi daya gugah dan daya ubah bagi umat yang sedang dilanda pandemi covid-19 dan bencana alam. Berdasarkan hal tersebut karya katekese di masa pandemi mesti berangkat dari pengalaman konkret penderitaan umat yang paling terdampak baik karena bencana alam maupun karena pandemi covid-19. Metode berkatekese dan berteologi semacam inilah yang ditawarkan oleh Kosuke Koyama agar karya katekese dan pembinaan iman umat dapat membantu mereka yang terdampak bencana keluar dari realitas penderitaan. Sebab pelaksanaan tugas pengajaran dan pembinaan iman tidak lagi dilaksanakan secara konvensional seperti perjumpaan langsung sebelum pandemi. Gereja mewujudkan panggilan tersebut dengan memanfaatkan ruang virtual.

Ruang virtual dengan media komunikasi digital yang canggih dan mutakhir memungkinkan Gereja untuk tetap melaksanakan karya katekese dengan baik dan tidak terhalang oleh ruang dan waktu. Gereja dapat memanfaatkan sarana ini secara maksimal melalui konten-konten media sosial seperti Whatsapp dan youTube yang marak digunakan oleh umat baik yang berpendidikan tinggi maupun umat sederhana di desa-desa. Melalui media sosial ini karya keselamatan Allah tetap menyentuh umat dimana dan kapanpun. Selain itu melalui konten-konten ini karya katekese dapat dikembangkan secara lebih dinamis, fleksibel dan hidup, karena melibatkan dimensi audio-visual, dan umat dalam ruang virtual ini dapat berinteraksi dan berperan aktif baik dengan pembina maupun dengan sesama umat. Dengan demikian dalam masa pandemi Gereja tetap melaksanakan karya keselamatan Allah secara maksimal.

\section{Referensi}

Ariyanto, M. D. (2011). Teologi Kristen Modern di Asia. Suhuf, 23(1), 68-101.

Asmara, D. (2021). Kurikulum Mitigasi Bencana. Retrieved 17 June 2021, from Jawa Pos website: https://www.jawapos.com/opini/20/01/2021/kurikulum-mitigasi-bencana/

Bala, K. (2020). Allah Tritunggal: Allah Yang Bersahabat. In F. X. Kurniawan, Markus Situmorang, \& C. V. Setiawan (Eds.), Kamu adalah Sahabatku (Vol. 30, pp. 243-276). Malang: STFT Widya Sasana Malang.

Banjir Kalsel Momen Kritis. (2021). Kompas Nusantara, p. 11.

BBC. (2011). Indonesia negara rawan bencana. Retrieved 17 June 2021, from BBC website: https://www.bbc.com/indonesia/berita_indonesia/2011/08/110810_indonesia_tsunami

Brata, A. A. (2019). Manfaat Penggunaan Media Sosial Whatsapp Dalam Pewartaan Iman Bagi Umat Di Lingkungan Santo Tarsius Sidomulyo Paroki Santo Yosep Mendari Yogyakarta. Sanata Dharma.

Budianto, A. S. (2018). Arah Katekese Indonesia. In R. P. Manik, A. Saptowidodo, \& A. S. Budianto (Eds.), 
Pembaharuan Gereja Melalui Katekese Superfisialisme, Aktivisme, Fundamentalisme dan Spiritualisme Tantangan Katekese Dewasa ini (pp. 204-239). Malang: STFT Widya Sasana Malang 2018.

Darmawan, D., Miharja, D., Waluyajati, R. S. R., \& Isnaeniah, E. (2020). Sikap Keberagamaan Masyarakat Menghadapi Wabah COVID-19. Religious: Jurnal Studi Agama-Agama Dan Lintas Budaya, 4(2), 115-124. https://doi.org/10.15575/rjsalb.v4i2.8596

Dewan Kepausan untuk Komunikasi Sosial. (2019). Gereja Dan Internet, Etika dalam Internet,Perkembangan Cepat. In A. Suparman \& B. H. T. Prasasti (Eds.), Dokumen Gerejawi. Jakarta: Depertemen Dokumentasi Dan Penerangan Konferensi Waligereja Indonesia.

Dey, W. F. B., \& Daro, M. P. (2016). Katekese Melalui Media Sosial; Mungkinkah? Atma Reksa: Jurnal Pastoral Dan Kateketik, 1(1), 21-29.

Djuraidah, A. (2009). Indeks Kerentanan Sosial Ekonomi Untuk Bencana Alam Di Wilayah Indonesia. Seminar Nasional Matematika Dan Pendidikan Matematika, 978-979.

Dwidiyanti, M., Hadi, I., Wiguna, R. I., \& Ningsih, H. E. W. (2018). Gambaran Risiko Gangguan Jiwa pada Korban Bencana Alam Gempa di Lombok Nusa Tenggara Barat. Holistic Nursing and Health Science, 1(2), 82-91. https://doi.org/10.14710/hnhs.1.2.2018.82-91

Embu, A. N. (2020). Pengalaman Postreligius Dan Media Sosial Digital Dalam Praktek Misa Online Di Masa Pandemi Covid-19. Jumpa: Jurnal Masalah Pastoral, 8(2), 20-49.

Fransiskus, P. (2015). Laudato Si' Terpujilah Engkau. In Adisusanto, M. Ratnaningsih, \& B. H. T. Prasasti (Eds.), Ensiklik Paus Fransiskus (Seri Dokum). Depertemen Dokumentasi Dan Penerangan Konferensi Waligereja Indonesia.

Fransiskus, P. (2019). Tentang Persaudaraan Manusia Untuk Perdamaian Dunia Dan Hidup Beragama. In Dokumen Abu Dhabi (Vol. 53, pp. 1689-1699).

Habur, A. M. (2018). Katekese Keluarga Di Era Digital. Jurnal Pendidikan Dan Kebudayaan Missio, 10(1), 39-47.

Hastuti, R. K. (2021). Data BNPB Per 18 Januari : 154 Bencana Alam , 140 Orang Tewas. Retrieved 17 June 2021, from CNBC Indonesia website: https://www.cnbcindonesia.com/news/20210119175208-4-217242/data-bnpbper-18-januari-154-bencana-alam-140-orang-tewas

Henakyn, M. M. (2016). Ensiklik Laudato Si': Perawatan Rumah Kita Bersama - Rumah Kita Ada Di Alam Ini. Jurnal Masalah Pastoral, 4(1), 29-45.

Iman Rahman Cahyadi. (2021). Kemkeu Catat Rata-rata Kerugian Akibat Bencana Capai Rp 22,85 Triliun Per Tahun. Retrieved 17 June 2021, from Berita Satu website: https://www.beritasatu.com/nasional/788401/kemkeu-catat-ratarata-kerugian-akibat-bencana-capai-rp2285-triliun-per-tahun

Irvin, D. T., \& Akinade, A. E. (2009). Rejoicing in Hope a Tribute to Kosuke Koyama. International Bulletin of Missionary Research, 33(3), 138-139. https://doi.org/10.1177/239693930903300308

Iswarahadi, Y. I. (2013). Inter Mirifica: Dalam Semangat Konsili Vatikan II Memahami dan Mengintegrasikan Media Komunikasi Sosial dalam Karya Pastoral Gereja. Jurnal Orientasi Baru, 22(2), 111-124.

Jubba, H. (2021). Beradaptasi dengan Bencana: Strategi Beribadah Umat Islam dan Kristen di Tengah Pandemi Covid-19. Religious: Jurnal Studi Agama-Agama Dan Lintas Budaya, 5(1), 1-14. https://doi.org/10.15575/rjsalb.v5i1.11164

Khairul Rahmat, H., \& Alawiyah, D. (2020). Konseling Traumatik: Sebuah Strategi Guna Mereduksi Dampak Psikologis Korban Bencana Alam. Jurnal Mimbar: Media Intelektual Muslim Dan Bimbingan Rohani, 6(1), 34-44. https://doi.org/10.47435/mimbar.v6i1.372

Komisi Kateketik KWI. (2015). Hidup Di Era Digital; Gagasan Dasar Dan Modul Katekese. Yogyakarta: Kanisius.

Koyama, K. (1974). Waterbuffalo Theology. Maryknoll, New York: Orbis Books.

Koyama, K. (1984). The Asian Approach to Christ. Missiology: An International Review, 12(4), $435-447$. https://doi.org/10.1177/009182968401200404

Koyama, K. (1997). My Pilgrimage in Mission. International Bulletin of Missionary Research, 21(2), 55-59. https://doi.org/10.1177/239693939702100203

Koyama, K. (1999). A theological reflection on religious pluralism. Ecumenical Review, 51(2), $160-171$. https://doi.org/10.1111/j.1758-6623.1999.tb00025.x

Kristianto, R. Y. (2016). Pentingnya Komunikasi Iman Melalui Diskursus Iman Di Dunia Digital. Jurnal Teologi, 5(01), 59-76. https://doi.org/10.24071/jt.v5i1.481

Makahaghi, Y. B., \& Surudani, C. J. (2021). Pengalaman Keluarga Menghadapi Trauma Pasca Bencana Alam di Kampung Lebo Kecamatan Manganitu. Jurnal Ilmiah Sesebanua, 5(1), 23-30.

Manurung, K. (2020). Efektivitas Misi Penginjilan dalam Meningkatkan Pertumbuhan Gereja. DUNAMIS: Jurnal Teologi Dan Pendidikan Kristiani, 4(2), 225-233. https://doi.org/10.30648/dun.v4i2.242

Mathiesen, G. (1998). Kosuke Koyama: Waterbuffalo Theologian An investigation into the theology of Kosuke Koyama I . 
Introduction to the Background of Kosuke Koyama. Minnesota. Retrieved from https://www.academia.edu/41403946/KOSUKE_KOYAMA_WATERBUFFALO_THEOLOGIAN_An_invest igation_into_the_theology_of_Kosuke_Koyama

Missa, O. R. (2020). Penggunaan Teknologi Komunikasi Digital Sebagai Tawaran Sarana Pelayanan Pastoral Di Tengah Pandemi. Atma Reksa: Jurnal Pastoral Dan Kateketik, 5(1), 36-45.

Moe, D. T. (2017). The Crucified Mind: Kosuke Koyama's Missiology of 'Theology of the Cross'. Exchange, 46(1), 5-28. https://doi.org/10.1163/1572543X-12341428

Nainggolan, B. (2014). Konsep Amanat Agung Berdasarkan Matius 28:1820 Dalam Misi. Jurnal Koinonia, 8(2), 1545.

Nota Pastoral KWI. (2013). Nota Pastoral Konferensi Waligereja Indonesia: Keterlibatan Gereja dalam Melestarikan Keutuhan Ciptaan. Jakarta.

Nouwen, H. J. M., Mcneill, D. P., \& Morrison, D. A. (1987). Sehati Seperasaan (W. S. G. Pau, Ed.). Yogyakarta: Kanisius.

Pandor, P. (2014). Aktualisasi Spritualitas Pasionis Di Tengah Orang-Orang Tersalib Zaman Ini. In E. R. L. Tinambunan \& K. Bala (Eds.), Di Mana Letak Kebahagiaan? (pp. 81-104). Malang: STFT Widya Sasana Malang.

Pandor, P. (2018). Kontribusi Teori Ujaran Dan Tindakan Bahasa Dalam Filsafat Aanalitik John Langshaw Austin Terhadap Bahasa Pewataan. In R. P. Manik, A. Saptowidodo, \& A. S. Budianto (Eds.), Pembaharuan Gereja Melalui Katekese Superfisialisme, Aktivisme, Fundamentalisme dan Spiritualisme Tantangan Katekese Dewasa ini (pp. 173-195). Malang: STFT Widya Sasana Malang 2018.

Paus Yohanes Paulus II. (1965). Dokumen Gereja : Dekrit Tentang Kegiatan Misioner Gereja. In Dokumen Gereja. Jakarta: KOMKAT-KWI.

Purwatma, M. (2016). Internet Dan Pewartaan Dalam Pesan Paus Untuk Hari Komunikasi Sedunia 2002-2016. Orientasi Baru, 25(1), 57-74.

Putranto, C. (2002). Instrumen kerja untuk mengevaluasi sebuah dokumen tercetak kateketik (Vol. 58). Yogyakarta.

Raharso, A. T. (2019). Reksa Pastoral Gereja Di Era Revolusi IndustrRi 4.0 (Tinjauan Hukum Gereja). In C. Valentinus, A. D. Firmanto, \& B. A. Pareira (Eds.), Siapakah Manusia; Siapakah Allah Menyingkap Tabir Manusia Dalam Revolusi Industri Era 4.0. Malang: STFT Widya Sasana Malang.

Rantesalu, M. B. (2020). Penderitaan dari Sudut Pandang Teologi Injili. Jurnal Ilmiah Religiosity Entity Humanity (JIREH), 2(2), 126-135. https://doi.org/10.37364/jireh.v2i2.46

Republika. (2021). Waspada, Banjir dan Longsor Masih Mengintai. Retrieved 17 June 2021, from Republika website: https://www.republika.id/posts/13646/waspada-banjir-dan-longsor-masih-mengintai

Ridlo, I. A. (2020). Pandemi COVID-19 dan Tantangan Kebijakan Kesehatan Mental di Indonesia. INSAN Jurnal Psikologi Dan Kesehatan Mental, 5(2), 162-171. https://doi.org/10.20473/jpkm.V5I22020.162-171

Rizky, F. (2021). Indonesia Rawan Bencana , Jokowi Ingatkan Jajarannya Jangan Sibuk Bikin Aturan. Retrieved 17 June 2021, from Sindonews.com website: https://nasional.sindonews.com/read/352974/15/indonesia-rawanbencana-jokowi-ingatkan-jajarannya-jangan-sibuk-bikin-aturan-1614758606

Sabir, A., \& Phil, M. (2016). Gambaran Umum persepsi masyarakat terhadap bencana di Indonesia. Jurnal Ilmu Ekonomi Dan Sosial, 5(3), 304-326.

Siahaya, J., Siahaya, K. M., \& Rinukti, N. (2020). Tuhan Ada di Mana-mana: Mencari Makna bagi Korban Bencana di Indonesia. Kurios, 6(1), 103. https://doi.org/10.30995/kur.v6i1.147

Stevanus, K. (2019). Kesadaran Akan Allah Melalui Penderitaan Berdasarkan Ayub 1-2. DUNAMIS: Jurnal Teologi Dan Pendidikan Kristiani, 3(2), 111-134. https://doi.org/10.30648/dun.v3i2.182

Sumartiningtyas, H. K. N. (2021). Gletser Himalaya Longsor, Ilmuwan Telah Peringatkan. Retrieved 17 June 2021, from Kompas website: https://www.kompas.com/sains/read/2021/02/08/192600023/gletser-himalayalongsor-ilmuwan-telah-peringatkan?page=all

Sunanto. (2014). Bencana Alam sebagai Alarm Kemanusiaan. Retrieved 17 June 2021, from Koran Sindo website: https://nasional.sindonews.com/read/306674/18/bencana-alam-sebagai-alarm-kemanusiaan-1611046911

Timo, E. N. (2017). encarian Kesaksian Kristen Yang Relevan Di Asia (Kosuke Koyama: Injil Menurut Pandangan Asia). Jurnal Ledalero, 12(2), 289-310. https://doi.org/10.31385/jl.v12i2.93.289-310

Tinambunan, E. R. L. (2018). Kelahiran Katekese. In R. P. Manik, A. Saptowidodo, \& A. S. Budianto (Eds.), Pembaharuan Gereja Melalui Katekese Superfisialisme, Aktivisme, Fundamentalisme dan Spiritualisme Tantangan Katekese Dewasa ini. Malang: STFT Widya Sasana.

Utomo, M. H., \& Minza, W. M. (2018). Perilaku Menolong Relawan Spontan Bencana Alam. Gadjah Mada Journal of Psychology (GamaJoP), 2(1), 48-59. https://doi.org/10.22146/gamajop.31871

Wijiyo, S. (2021). Banjir-Longsor dan Narasi Fikih Lingkungan. Retrieved 17 June 2021, from Jawa Pos website: https://www.jawapos.com/opini/19/02/2021/banjir-longsor-dan-narasi-fikih-lingkungan/?page=all

Wijoyo, S. (2021). Memaknai Bencana di "Kepingan Surga". Retrieved 17 June 2021, from Jawa Pos website: 
https://www.jawapos.com/opini/19/01/2021/memaknai-bencana-di-kepingan-surga/

Yahya, A. N. (2021). Siaga La Nina, Pemerintah Diminta Siapkan Rencana Aksi untuk Daerah Rawan Bencana.

Retrieved 17 June 2021, from Kompas website:
https://nasional.kompas.com/read/2020/10/11/13113951/siaga-la-nina-pemerintah-diminta-siapkanrencana-aksi-untuk-daerah-rawan?page=all

Yohanes Paulus II. (2011). Dekrit tentang upaya-upaya komunikasi sosial. In Dekrit Yohanes Paulus II. Jakarta: KOMSOS-KWI.

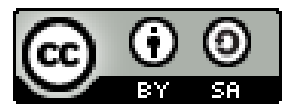

(C) 2021 by the authors. Submitted for possible open access publication under the terms and conditions of the Creative Commons Attribution (CC BY SA) license (https://creativecommons.org/licenses/by-sa/3.0/). 